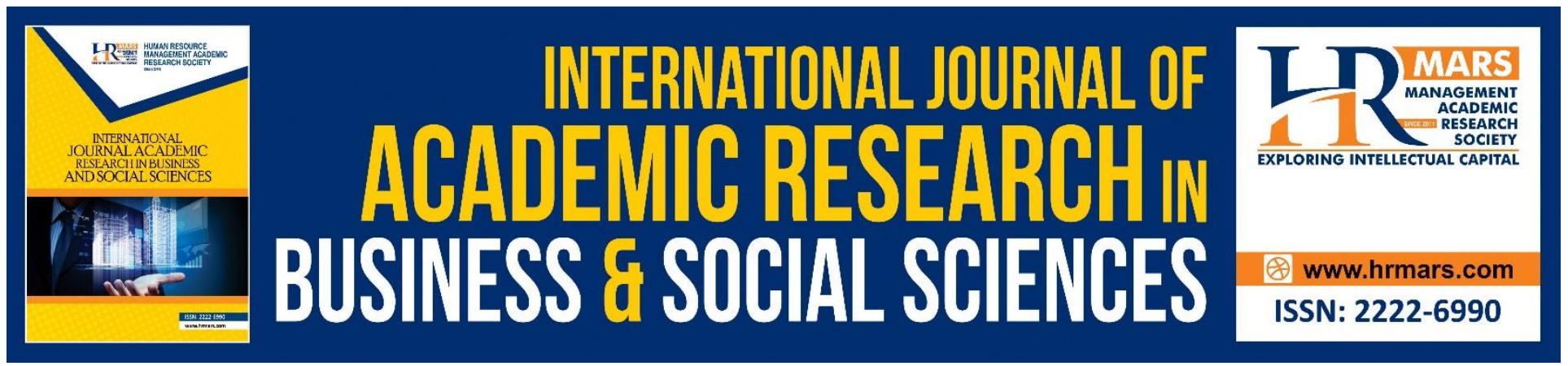

\title{
The Causation of the Financial Statement Manipulation Activities
}

Norfadzilah Rashid, Asyraf Afthanorhan, Ahmad Shukri Yazid, Razana Juhaida Johari, Nadiah Abdul Hamid, Zarinah Abdul Rasit

To Link this Article: http://dx.doi.org/10.6007/IJARBSS/v8-i12/5264

DOI: $10.6007 /$ IJARBSS/v8-i12/5264

Received: 21 Oct 2018, Revised: 26 Dec 2018, Accepted: 30 Dec 2018

Published Online: 13 Jan 2019

In-Text Citation: (Rashid et al., 2018)

To Cite this Article: Rashid, N., Afthanorhan, A., Yazid, A. S., Johari, R. J., Hamid, N. A., \& Rasit, Z. A. (2018). The Causation of the Financial Statement Manipulation Activities. International Journal of Academic Research in Business and Social Sciences, 8(12), 1629-1637.

Copyright: (C) 2018 The Author(s)

Published by Human Resource Management Academic Research Society (www.hrmars.com)

This article is published under the Creative Commons Attribution (CC BY 4.0) license. Anyone may reproduce, distribute, translate and create derivative works of this article (for both commercial and non-commercial purposes), subject to full attribution to the original publication and authors. The full terms of this license may be seen at: http://creativecommons.org/licences/by/4.0/legalcode

Vol. 8, No. 12, 2018, Pg. 1629 - 1637

http://hrmars.com/index.php/pages/detail/IJARBSS

JOURNAL HOMEPAGE

Full Terms \& Conditions of access and use can be found at http://hrmars.com/index.php/pages/detail/publication-ethics 


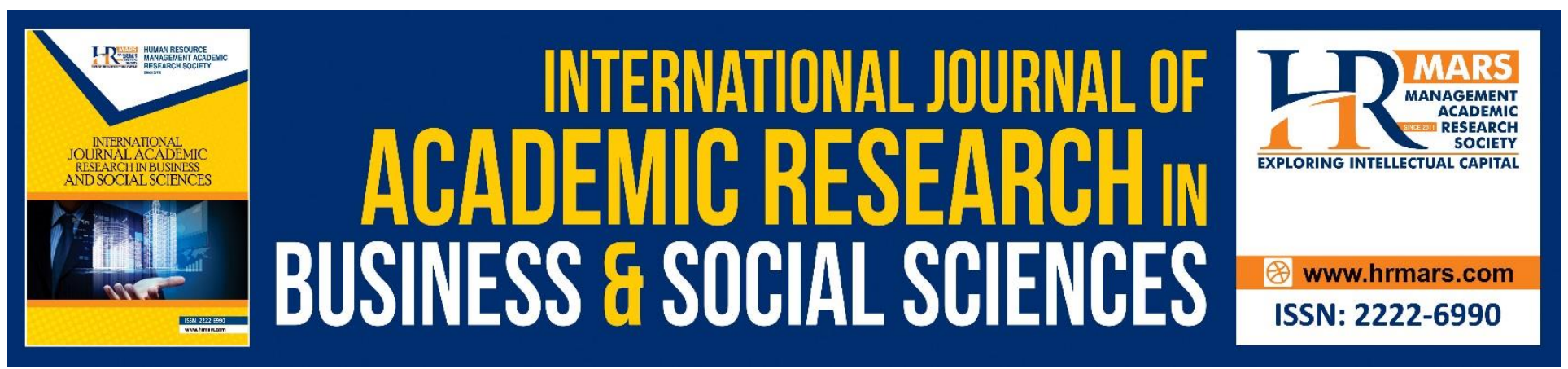

\title{
The Causation of the Financial Statement Manipulation Activities
}

\author{
Norfadzilah Rashid, Asyraf Afthanorhan, Ahmad Shukri Yazid, Razana \\ Juhaida Johari, Nadiah Abdul Hamid, Zarinah Abdul Rasit \\ 1,2,3 Faculty of Economic and Management Science, Universiti Sultan Zainal Abidin, Gong Badak \\ Campus, Terengganu, Malaysia \\ 4,5,6Faculty of Accountancy, Universiti Teknologi MARA, 41450 Shah Alam, Selangor, Malaysia
}

\begin{abstract}
Nowadays, one of the biggest problems that being face by the financial institution is fraudulent in the business transaction. It is one of the serious problems that causes many companies loses of hundred billion of dollar. It is considered as white-collar crimes as it involve many key players of the financial industry and from the company itself. The most common fraudulent is the financial statement fraud (FSF). It is an attempt to deceive the financial player regarding the actual status of the company. It's the consequences of the ethical behaviour from financial information provider in preparing their financial statement. So, in this article will define the meaning of the financial statement fraud, presenting the biggest cases that have happened in the past years, how the company 'cooking the books' and it consequences, and suggest how to prevent the financial fraud in the future. To prevent the financial fraud, the government participation is essential as the government have the power to authorize the regulation regarding prevention of financial fraud. One of the regulations that is famous in preventing financial fraud is using Sarbanes-Oxley Act of 2002, which is used to revamp the standard of financial report, corporate governance and cogency of auditor. The variable for this article is the deterring financial fraud and the understanding the element which lead to financial statement fraud.
\end{abstract}

\section{Introduction}

Basically, the definition of financial fraud can be classified as a fraudulent act of financial transaction with a view to personal gain. Fraud is one of the crimes, which is against civil law. Most of the cases of fraud contain financial transactions that are difficult to identify with their offenses committed by 'white collar villains' such as professionals who have high knowledge and have criminal intentions. There are 3 factors for why financial fraud, which is stress, rationalization and opportunity, (Rashid, Asfthanorhan, et al., 2018). Stress is existing because of other people. For instant, pressure from family members, a spouse or his friend can lead a person on the path of fraud. Pressure can also force 
various human behaviours that sometimes cause fraud such as recognise revenue in the wrong period of time, (Alfadhli, Rashid, \& Yaakub, 2018).

Second, rationalization is the logical thinking of the manager where to prove and defence the reputation of the financial condition of the company. Sometimes it's just justified. For example, the worker did not get promotion, salary or even 10-year remuneration may say the company owes it to him, so the person makes a scam for money that he thinks it's been too late. Fraud is not necessarily in large amount. Fraud in small amounts is also a crime. Employees have always assumed that thefts in small amounts do not cause the company to suffer huge losses, (Jamal, Daud, Zainol, Rashid, \& Afthanorhan, 2018). Chance, this is the strongest factor in the fraud triangle. if somebody is under pressure to break fraud or have rationalized the idea so there is no benefit, this is impossible to make fraud without any opportunity to do so. The biggest case for financial fraud is the 'Enron Scandal'. Enron was created for Kenneth Lay after successfully combining the two largest energy companies in Texas, Houstan Natural Gas and Internorth in 1985. In 1992, the company became the largest provider of natural gas and also has various pipelines and power plants at state level as well as the world. The principle behind this scandal, Jeffrey Skilling, CEO of Enron, with other officers made various accounting methods and loopholes to hide billions of dollars in debt from stakeholders and board of directors, (Rashid, Daud, et al., 2018). After the company was bankrupt, its shareholders lost about $\$ 74$ billion together with retirement and employment funds. Enron's case also raises new questions about ethics of corporate watchdogs like Arthur Anderson, Enron's auditor.

\section{Financial Statement Fraud}

According to (Musibau et al., 2018), there is five interactive factors which is called end-cooks, recipe, incentive, monitoring and end result, which given in the short word called CRIME (Ali, Abdullah, \& Rashid, 2018). These factors are providing a huge contribution to the financial fraud, these factors emphasize more the understanding of causes and effective of financial statement fraud. This is because many organization businesses they are trying to hide the real document that show the agreement with suppliers that will provide information about the organization transaction, but sometime fraud may be caused by the CEO of the company or group of the auditors, (Masud, Daud, Zainol, Rashid, \& Asyraf, 2018). But it is not only that, a financial fraud may be happen with different situation may be by known or unknown. There is so many reasons and causes that lead to financial fraud and not only that five interactive factors which know in short as CRIME, sometime financial fraud may occur in recognition of revenue in the wrong accounting period, or sometime withholding money with suppliers and also manipulating over the business cost, (Hamid et al., 2018). Those situations may cause fraud to the business financial reporting, so the organization should be aware with any situation that may cause a fraud to the financial statement because now day people are seeking for the information in every corner of the world to know what is going on to the wold of business, (Yazid, Yuhafidz, et al., 2018).

\section{Strategy of Detection and Prevention of Fraud Risk}

Controlling and preventing the fraud is not easy as we think, it requires to have higher knowledge, therefore, a company or organizations should develop fraud detection and prevention program. First they have to establish the fraud policy; where the organization may meet its expectation, of risk in 
the policy approach was been established, also they have to asses where the organization has fraud exposure, (Hashim, Hamid, \& Rashid, 2018). Second, they have to establish fraud risk assessment and fraud prevention control; the organization they have to develop a new system of controlling activities to manage the risk, to be wide control, example fraud awareness training and ethic policy to be in specific to a different part of risk like quick regression of the duty of the transaction, (Dakhlallh et al., 2018). Third they have to establish fraud detection control, by communicating, monitoring and reporting the fraud statement that could be ongoing and continuing, also in other hand internal company audit should attempt on the role to observe the fraud risk either the fraud control is operating effectively and efficiency. Also, organization should develop a new software system that will manage to conduct the information precisely obtained by company and also to the top manager committees as evidence of fraud arise regarding of materiality.

\section{Corporate Governance}

Financial fraud can be defined as intentional deception in organization about their financial reports for the purpose of illicit reasons and personal gains. It has occur in many countries and companies all across the world. It is safe to say that most of the company, to say the least, must have involve in financial fraud. The reason of not been caught is obviously because it still not being exposed or they handle it very discreetly that in some cases, they might have slip through the hand of law enforcer unnoticed. One example of financial fraud that always occurred is cooking the book. Cooking the book means management intentionally manipulate financial reports. Top executives who involve in cooking the book can be say they will barred by Securities and Exchange Commission (SEC), force to early retirement, being burden by fines and losing the value of their stock-based compensation (Rashid, Wan, Shaari, \& Afthanorhan, 2018). They should aware of these consequences and avoid of doing any unethical things, whether can gain benefits out of it or not.

Corporate governance is important in business organization. It plays its vital role in managing company to strive for a good profit and sustain for a long-term. But, if it falls into wrong hand, it might put the company into risks. As many cases that happened for the last year, corporate governance was always become the factor to financial fraudulent. Most of the cases tell that corporate governance is always lack in responsible (Ghazali, Mamat, Mohamed, Muhamad, \& Rashid, 2018). Corporate governance was supposedly eliminating any elements of fraud in their organization. So, corporate governance should consist of vigilant board of directors and audit committee (Rashid, Ghaffar, Mokhtar, Yazid, \& Afthanorhan, 2018). By having this kind of corporate governance, it can create an environment that demand high-quality financial report only, which should be truth and fairness. Because, financial statement users are all expecting a clean report that reflect the condition of the company. Otherwise, the company might lose their potential investor and creditor.

Sarbanes Oxley Act 2002 (SOX) was enacted because of financial fraud case that happened years ago that caught world attention. Sarbanes Oxley Act 2002 (SOX) also exist to improve corporate governance, quality of financial report and credibility of audit functions. This act can supervise responsibility in the area of corporate governance, financial reporting, internal control structure and audit functions (Yazid, Hassan, et al., 2018). It banned the company give loan to executives and job protection to whistle-blower. 
There are six sections out of Sarbanes Oxley Act 2002 (SOX) which are section 302, 303, 401, 404, $802,806,906$ and 1107 . Section 302 is about the responsibility of the CEO and CFO for the accuracy, documentation and submission of financial reports. Sections 303 comprises of four things which are rules to prohibit, enforcement, no pre-emption of other law and deadline for rulemaking. Section 401 require the disclosure of all off-balance sheet items. Meanwhile, section 404 is about internal control report that must be included in the financial reports. The management need to do assessment on their internal control to test the effectiveness of the internal control. This section is being considered the most complicated to adopt, most contested and most expensive of all the sections for compliance. The purposes of its existence is to regulate financial reporting and other business practices at corporate sector. Section 802 is penalty for influencing US agency investigation and section 806 whistle-blower protection provision for those who expose fraud in their organization. Section 906 is for CEO and CFO who are fail to certify financial reports and section 1107 is criminal penalties against those who retaliate whistle-blower. Adoption of provision of Sarbanes Oxley Act 2002 (SOX) can improve independence, objectivity and effectiveness of the audit committee and corporate governance (Rashid, Mustapha, et al., 2018).

\section{Impact of Financial Statement Fraud}

Financial statement fraud is intentionally attempt by a company to cheat or to mislead figure in the financial statement and this cause problems toward the users of the reporting that consisting the investor and creditors. The fraud occurred were made by the clever team of knowledgeable perpetrators and they were already setting up all the plan to deceive the statement with cunning, (Rashid, Mustapha, et al., 2018). A corporation should prepare and disseminate their financial reporting that are reliable, transparent and with uniformity in order for the users to make decisions wisely. By acting unethically such as overstating the revenue and/or understating expenses might confuse the public and eventually loss in confidence toward the company.

Several impact or consequences that might affect the public users of the 'crime' made by this corporation are very huge. The reduction of the share price of the stock substantially is one of the impacts that happened. The decrease in the price of the share may affect the wealth of the investor if the fall is so significant. It will affect their financial outlook. They may be feeling hesitate to invest more if they are losing their money.

Next, facing lawsuits by the parties whom incurred huge losses because relying to the financial statement containing material misstatement and fraud. Past cases showing that auditor always being sued because of their negligent in showing or failing to report the shareholder/investor that the audited financial statement is fairly stated, (Bello, Yazid, Wan, Rashid, \& Afthanorhan, 2018). Often the action of fraud made by the management of the company such as manipulate the earnings in the financial statement to show good performance resulting the shareholder to blame the auditor because fail to detect the fraud. Famous fraud cases have ever happened is the case of Enron that they are hiding debt, creating common equity and overstate earnings. This is at first give a good impression towards the investor to invest but eventually when the company went bankrupt, a lot of investor being deceived because of their actions, (Yazid, Arifin, et al., 2018). These frauds involving the auditor as well as they are conspiring with the management to manipulate the financial statement. Both Enron and the audit company are bankrupt because causing too many losses and 
being sued by the parties involved. In addition to that, the impact of the financial statement fraud also gives bad effect to the company's reputation. The occurrence of the fraud will lead to the loss of confidence of investor that investing their money into the company, (Yazid, Arifin, et al., 2018). The investor put their money into the company so that they will get profit in return. If the company itself already destroyed their trust in order to increase their wealth, there is nothing to be dealt next unless they stop investing with the current company and find new profitable company that able to manage their capital.

Besides that, the company that involved with fraudulent activities are not able to last long. They cannot survive in the capital market to continue their business operations day to day. Soon or later the public/authority may discover their illegal activities, (Fakrulhazri, Norhayate, Zainol, Rashid, \& Afthanorhan, 2018). Once uncovered, the investor will run, and the company start being sued by a lot of side such as the banks if they are unable to repay their debt to the public because ruin their trust and money invested, and list go on. The company started liable with damages, penalties, and fines by the court and usually involving up to billion dollars. They then later are not able to repay all that because of their performance showing loss of profit and then lead to the bankruptcy.

\section{Conclusion}

Financial fraudulent activities is flooding the corporate governance. It's a serious threat to the market participant either the external or internal members who are involved in the financial statement either direct or indirect. Fraudulent activities in financial statement are criminal that subjected to the law. The offenders our culprit will be charges with the legal action. The factors that may occurs in other to engage in the financial fraudulent activities. Whereby, firm's structure weakness and the corporate body become less effective and the quality of auditing function was slump.

Beside that company also can cheat by claiming their fraudulent transaction is actually closed according to GAAP requirement such as issuing this fraud activities as accounting practise. Therefore, the audit committee should advice and motivate the company not to convict with fraudulent transaction activities that will lead to provide a wrong information to financial reporting.

Also, final factor that may affect to the fraudulent financial statement activities is to provide a good opportunity to ensure or perpetuate the financial fraud because of there is no responsible and the company was failing to keep eye on this fraud activities. The record was listing the Enron case as the one of the big name that engage with the fraudulent activities. Beside Enron there could be WorldCom case, stated it's about 3.8 million expense were hidden. Hence, Parmalat cases are the huge cases which show the company was engage with the fraudulent activities which is $\$ 3.95$ billion cash fund in the bank of America in the company was discovered to be non-existence in 2003 . There show several cases were discuss on this article. Lastly, the consequences that may affect the entity when they were engage with the fraud financial statement. Firstly, the legal liability to the entity thus, the internal and external parties. Besides that, the moral and ethical to against the entity and community last is the company who are not avoid the fraudulent financial statement activities may cause to the bankruptcy.

\section{References}

Alfadhli, M. I., Rashid, N., \& Yaakub, N. (2018). The Impact of Internal Audit and its Quality on Sales 
INTERNATIONAL JOURNAL OF ACADEMIC RESEARCH IN BUSINESS AND SOCIAL SCIENCES

Vol. 8, No. 12, Dec, 2018, E-ISSN: 2222-6990 @ 2018 HRMARS

in Economic Institutions : A Case Study ( Al-Ahlia Cement Company - Libya ) The Impact of Internal Audit and its Quality on Sales in Economic Institutions : A Case Study ( Al-Ahlia Cement Company - Lib. International Journal of Academic Research in Business and Social Sciences, 8(8), 50-65. https://doi.org/10.6007/IJARBSS/v8-i8/4434

Ali, A. R., Abdullah, B., \& Rashid, N. (2018). An Error Analysis Approach in Identifying the Patterns of Mistakes in Jawi Spelling An Error Analysis Approach in Identifying the Patterns of Mistakes in Jawi Spelling. International Journal of Academic Research in Business and Social Sciences, 8(11), 1222-1231. https://doi.org/10.6007/IJARBSS/v8-i11/5164

Bello, B. A., Yazid, A. S., Wan, N., Rashid, N., \& Afthanorhan, A. (2018). Problems of Social Security : An Islamic Remedy Problems of Social Security : An Islamic Remedy. International Journal of Academic Research in Business and Social Sciences, 8(11), 1447-1464.

https://doi.org/10.6007/IJARBSS/v8-i11/5203

Dakhlallh, M., Rashid, N., Yazid, A. S., Salleh, F., Afthanorhan, A., \& Ghazali, P. L. (2018). An Investigation of Corporate Governance Mechanisms on Real Earnings Management toward the Changes on Firm Performance : Evidence from Jordan An Investigation of Corporate Governance Mechanisms on Real Earnings Management toward the Changes on Firm Perfor. International Journal of Academic Research in Business and Social Sciences, 8(11), 1389-1400. https://doi.org/10.6007/IJARBSS/v8-i11/5198

Fakrulhazri, N., Norhayate, W. D., Zainol, F. A., Rashid, N., \& Afthanorhan, A. (2018). The Shared Value Concept in Social Business Model : Promoting Social Enterprise in Malaysia The Shared Value Concept in Social Business Model : Promoting Social Enterprise in Malaysia. International Journal of Academic Research in Business and Social Sciences, 8(11), 1508-1520. https://doi.org/10.6007/IJARBSS/v8-i11/5208

Ghazali, P. L., Mamat, M., Mohamed, S. B., Muhamad, W., \& Rashid, N. (2018). Analysis of the Acceptance of Newly Constructed Takaful Education Plan for Learning Disabled Children among Public Analysis of the Acceptance of Newly Constructed Takaful Education Plan for Learning Disabled Children among Public. International Journal of Academic Research in Business and Social Sciences, 8(11), 1413-1420. https://doi.org/10.6007/IJARBSS/v8-i11/5200

Hamid, N. A., Aisyah, H., Taib, M., Noor, R., Yaacob, Z., Shamsuddin, R., ... Afthanorhan, A. (2018). The Effect of Tax Reforms on Tax Agents' Job Burnout in Malaysia The Effect of Tax Reforms on Tax Agents ' Job Burnout in Malaysia. International Journal of Academic Research in Business and Social Sciences, 8(12), 547-560. https://doi.org/10.6007/IJARBSS/v8-i12/5054 Hashim, N. H., Hamid, N. A., \& Rashid, N. (2018). Assessing Job Performance of Tax Agents via EFiling System Assessing Job Performance of Tax Agents via E-Filing System. International Journal of Academic Research in Business and Social Sciences, 8(11), 1369-1378. https://doi.org/10.6007/IJARBSS/v8-i11/5196

Jamal, R., Daud, W. N. W., Zainol, F. A., Rashid, N., \& Afthanorhan, A. (2018). Unlocking "Black Box ": Mediating Role of Knowledge Process Capability on HRM Practices and Innovative Performance Unlocking " Black Box ": Mediating Role of Knowledge Process Capability on HRM Practices and Innovative Performance. International Journal of Academic Research in Business and Social Sciences, 8(11), 1192-1208. https://doi.org/10.6007/IJARBSS/v8-i11/5162

Masud, H., Daud, W. N. W., Zainol, F. A., Rashid, N., \& Asyraf, A. (2018). A critique of normative 
INTERNATIONAL JOURNAL OF ACADEMIC RESEARCH IN BUSINESS AND SOCIAL SCIENCES

Vol. 8, No. 12, Dec, 2018, E-ISSN: 2222-6990 @ 2018 HRMARS

commitment in management research. International Journal of Academic Research in Business and Social Sciences, 8(11), 1172-1191. https://doi.org/10.6007/IJARBSS/v8-i11/5161

Musibau, H. O., Mahmood, S., Ismail, S., Shamsuddin, Z., Rashid, N., \& Mahmood, S. (2018). Does

External Debt Cause Economic Growth ? An Experience from ECOWAS Member Countries Does External Debt Cause Economic Growth ? An Experience from ECOWAS Member Countries. International Journal of Academic Research in Business and Social Sciences, 8(11), 1256-1264. https://doi.org/10.6007/IJARBSS/v8-i11/5167

Rashid, N., Asfthanorhan, A., Johari, R. J., Hamid, N. A., Yazid, A. S., Salleh, F., ... Salleh, F. (2018). Ethics and Financial Reporting Assurance. International Journal of Academic Research in Business and Social Sciences, 8(11), 1346-1355. https://doi.org/10.6007/IJARBSS/v8-i11/5176

Rashid, N., Daud, W. N. W., Zainol, F. A., Salleh, F., Yazid, A. S., Endut, W. A., ... Ghazali, P. L. (2018). The Uses of Financial Reporting Standard for Small Medium Enterprise Companies The Uses of Financial Reporting Standard for Small Medium Enterprise Companies. International Journal of Academic Research in Business and Social Sciences, 8(11), 1331-1338.

https://doi.org/10.6007/IJARBSS/v8-i11/5174

Rashid, N., Ghaffar, M., Mokhtar, M. Z., Yazid, A. S., \& Afthanorhan, A. (2018). EA adoption in Malaysian Maritime Industry : A Conceptual Study and Future Direction E-Accounting adoption in Malaysian Maritime Industry : A Conceptual Study and Future Direction. International Journal of Academic Research in Business and Social Sciences, 8(11), 1421-1436. https://doi.org/10.6007/IJARBSS/v8-i11/5201

Rashid, N., Mustapha, U. A., Hamid, N. A., Rasit, Z. A., Yazid, A. S., \& Afthanorhan, A. (2018). The Mediating Effect of CEO Characteristics on the Relationship between Corporate Governance Attributes and Earnings Management in Nigerian Financial Sector : Proposed Conceptual Framework The Mediating Effect of CEO Characteristics on the Relationship be. International Journal of Academic Research in Business and Social Sciences, 8(11), 1465-1477. https://doi.org/10.6007/IJARBSS/v8-i11/5204

Rashid, N., Wan, S., Shaari, M., \& Afthanorhan, A. (2018). Conceptual Analysis on Performance Measurement Used in SMEs Research : The Effectiveness of Firm 's Overall Performance Conceptual Analysis on Performance Measurement Used in SMEs Research : The Effectiveness of Firm 's Overall Performance. International Journal of Academic Research in Business and Social Sciences, 8(11), 1401-1412. https://doi.org/10.6007/IJARBSS/v8-i11/5199

Yazid, A. S., Arifin, J., Rashid, N., Ghazali, P. L., Salleh, F., Mahmood, S., ... Rasit, Z. A. (2018). The Mediating Effects of Relationship Commitment-Trust between Innovation and Fairness on Loyalty in family Takaful : A Literature Review The Mediating Effects of Relationship Commitment- Trust between Innovation and Fairness on Loyalty in family Takaful. International Journal of Academic Research in Business and Social Sciences, 8(11), 1487-1497. https://doi.org/10.6007/IJARBSS/v8-i11/5206

Yazid, A. S., Hassan, M. F., Mahmood, S., Rashid, N., Salleh, F., Ghazali, P. L., \& Sadad, M. (2018). Organizational Factors in Enterprise Risk Management Effectiveness : A Conceptual Framework Organizational Factors in Enterprise Risk Management Effectiveness : A Conceptual Framework. International Journal of Academic Research in Business and Social Sciences, 8(11), 1437-1446. https://doi.org/10.6007/IJARBSS/v8-i11/5202 
INTERNATIONAL JOURNAL OF ACADEMIC RESEARCH IN BUSINESS AND SOCIAL SCIENCES

Vol. 8, No. 12, Dec, 2018, E-ISSN: 2222-6990 @ 2018 HRMARS

Yazid, A. S., Yuhafidz, M., Rashid, N., Ghazali, P. L., Salleh, F., \& Mahmod, M. S. (2018). A Mediating Effect of Risk Perception on Factors Influencing Tourist Intention To Travel : a Conceptual

Framework. International Journal of Academic Research in Business and Social Sciences, 8(11), 1246-1255. https://doi.org/10.6007/IJARBSS/v8-i11/5166 